\title{
INDUCTION OF THE ACROSOME REACTION OF GOLDEN HAMSTER SPERMATOZOA WITH BLOOD SERUM COLLECTED AT DIFFERENT STAGES OF THE OESTROUS CYCLE
}

\author{
C. BARROS, J. ARRAU AND E. HERRERA \\ Embryology Laboratory, Institute of Biological Sciences, \\ Catholic University of Chile, Santiago, Chile
}

(Received 1st January 1971, accepted 16th Fune 1971)

\begin{abstract}
Summary. Blood serum collected from female hamsters on each day of the oestrous cycle was assayed for its ability to induce the acrosome reaction. The maximum activity was found in sera obtained from females around the time of ovulation, and the minimum on Day 2. Ovariectomy did not affect the activity of the serum but oestrogen treatment significantly increased it. Blood serum from progesterone-treated and pregnant females significantly depressed the incidence of the acrosome reaction. Progesterone counteracted the effect of oestrogen with regard to the incidence of the acrosome reaction. The counteracting effect was maximal when both hormones were administered at the same time.

The possible rôle played by the hormones in this phenomenon is discussed.
\end{abstract}

\section{INTRODUCTION}

Barros \& Austin (1967) showed that oocytes recovered from preovulatory follicles could be fertilized in vitro with epididymal spermatozoa in the absence of any other secretion from the female tract. They also showed that a high incidence of the sperm acrosome reaction could be induced if epididymal spermatozoa were incubated in the presence of the contents of preovulatory follicles. The inference was then made that female tract secretions were not necessary for the occurrence of sperm capacitation.

Cow (Yanagimachi, 1969b; Gwatkin \& Andersen, 1969), mouse and rat (Yanagimachi, 1969a) follicular fluids were found to induce the acrosome reaction of hamster spermatozoa in vitro.

Furthermore, Yanagimachi $(1969 \mathrm{~b})$ found that there are at least two fractions in bovine follicular fluid which are important for the process of capacitation; one fraction is dialysable and heat stable at $90^{\circ} \mathrm{C}$ and has spermactivating properties, and a second fraction is non-dialysable and heat labile at $90^{\circ} \mathrm{C}$ and is responsible for the induction of the acrosome reaction. The same two fractions seem to be present in blood serum. The large molecular weight fraction appears to be albumin or to consist of substances closely associated with albumins (Yanagimachi, 1970). 
Hamster, rat, rabbit, human (Barros \& Garavagno, 1970; Yanagimachi, 1970), bull and guinea-pig (Yanagimachi, 1970) blood sera preheated at $56^{\circ} \mathrm{G}$ can readily induce the acrosome reaction of hamster spermatozoa in vitro. Barros \& Garavagno (1970) suggested that the agent that capacitates spermatozoa and is present in the female genital tract secretions, including the follicular fluid, might be synthesized in a place other than the genital tract and subsequently brought there by the blood stream. The results presented by Barros \& Garavagno (1970) seem also to suggest a sex dependence of the abilities of blood serum with regard to the induction of capacitation and the acrosome reaction, since female blood serum appeared to have better acrosome-reaction properties than male blood serum.

The relationship between capacitation of rabbit spermatozoa in the female genital tract and the reproductive phase of the female was demonstrated by Chang (1958). He showed that capacitation could be obtained in the uterus of immature and ovariectomized female rabbits, with or without gonadotrophin or oestrogen treatment. He also showed that capacitation was inhibited in the pseudopregnant or progesterone-dominated uterus. Chang's results were later confirmed by Hamner, Jones \& Sojka (1968). Soupart (1967), however, showed that human chorionic gonadotrophins enhance rabbit sperm capacitation with a clear dose-response relationship. Similar results were obtained by Wettemann $\&$ Hafs (1970). The gonadotrophin action is mediated through the ovary, since in ovariectomized females capacitation is almost completely abolished. Oestrogen injections into ovariectomized females restore the sperm-capacitating properties of the uterus (Soupart, 1967).

The purpose of this study was to investigate the effect of reproductive phase and of oestrogen and progesterone treatment on the acrosome-reaction-inducing properties of female hamster blood serum.

\section{MATERIAL AND METHODS}

\section{Recovery of spermatozoa}

Spermatozoa were obtained from the cauda epididymidis of mature, 5-monthold male hamsters. The cauda was blotted on a piece of filter paper to rid it of blood. Small incisions were made on the epididymis and then it was placed under mineral oil. A $0.15 \mathrm{M}$-sodium chloride solution, buffered with $0.1 \mathrm{M}$-tris at $\mathrm{pH}$ $7 \cdot 6$, was used to suspend spermatozoa. After $15 \mathrm{~min}$, the epididymis was removed and, later, a sample of spermatozoa was taken in order to determine their concentration.

\section{Recovery of blood serum}

Human blood was drawn from the cubital vein, and hamster blood was obtained by heart puncture or, under ether anaesthesia, from the abdominal aorta. The blood was transferred to chilled siliconized tubes, and left to clot at room temperature for almost $2 \mathrm{hr}$. The clotted blood was centrifuged for $10 \mathrm{~min}$ at $1500 \mathrm{rev} / \mathrm{min}$ on a clinical centrifuge. The clear serum thus obtained was placed under mineral oil in vials, and heated in a water bath for $1 \mathrm{hr}$ at $56^{\circ} \mathrm{C}$. The heated serum was stored at $5^{\circ} \mathrm{C}$ until use. 
Acrosome reaction assay of blood serum

The acrosome-reaction-inducing property of blood serum was assayed by incubating, under mineral oil, $1 \times 10^{4}$ spermatozoa $/ \mu$ l of serum. Preparations were made in disposable tissue culture Petri dishes (Falcon 3001), and incubated at $37.5^{\circ} \mathrm{C}$. Samples of spermatozoa were taken after $5 \mathrm{hr}$ incubation and examined under the phase-contrast microscope. Over 100 actively motile spermatozoa were counted and the incidence of spermatozoa with acrosomes which had undergone the reaction was recorded.

\section{Assay of the method}

Since our interest was to study the possible variation of the incidence of the acrosome reaction during the reproductive phase of the female hamster, it seemed necessary to determine the reliability of the method used in order to make sure that we would not have variations other than those under study. In preliminary studies, we compared the incidence of the acrosome reaction produced by an individual blood serum with that produced by pooled sera. We also compared the incidence of the acrosome reaction observed when spermatozoa were obtained from one male with that found when pooled spermatozoa from several males were used. Table 1 shows that the results obtained in the four experiments

TABLE 1

MEAN PERGENTAGE AGROSOME REACTIONS WITH MALE HUMAN BLOOD SERA UNDER DIFFERENT COMBINATIONS

\begin{tabular}{l|l|c|c|c}
\hline \multicolumn{1}{c|}{ Blood serum } & Spermatozoa & $\begin{array}{c}\text { No. of } \\
\text { experiments }\end{array}$ & $\begin{array}{c}\text { Mean } \\
\%\end{array}$ & S.E. \\
\hline Individual (10) & Individual (10) & 10 & 82.9 & $2 \cdot 6$ \\
Pool of ten males & Pool of ten males & 10 & $76 \cdot 1$ & $2 \cdot 6$ \\
& Individual (10) & 10 & 78.5 & $2 \cdot 7$ \\
& Pool of ten males & 10 & 89.3 & 1.4 \\
\hline
\end{tabular}

Numbers in parentheses indicate the numbers of individuals used.

are not significantly different. We also found no significant differences when blood serum was stored under mineral oil at $5^{\circ} \mathrm{C}$ for several days. In the light of these results and to economize on animals, spermatozoa were obtained in each experiment from one male and individual blood serum was used.

Effect of reproductive phase on the ability of blood serum to induce the acrosome reaction

Females kept under controlled light conditions (lights on from 06.00 until 21.00 hours) were used to provide blood during the different reproductive phases.

Normal cycling females. A group of mature female hamsters whose oestrous cycle was determined according to Orsini's (1961) method was used in this series of experiments. Only females showing at least four regular cycles were used as blood donors. Sixteen females were bled at 10.00 hours on Days 1, 3 and 4 , and thirteen females on Day 2 of the oestrous cycle, and the individual sera were assayed for the acrosome reaction. The day on which the white viscous discharge appeared in the vagina (Orsini, 1961) was considered as Day 1. 
Pregnant females. A group of fifteen pregnant females was bled on the 11 th day of pregnancy. Day 1 was taken as the day when spermatozoa were found in the vagina.

Ovariectomized females. A group of adult females with regular oestrous cycles was ovariectomized under Avertin anaesthesia and was then allowed to recover for 1 to $2 \frac{1}{2}$ months. After this time, the females were allotted to four groups as follows: Group 1: A group of forty-one females was ovariectomized. After full recovery they were bled and the serum assayed with hamster spermatozoa for the incidence of the acrosome reaction. In this group, as in the others, a careful examination was made to ensure that ovariectomy had been complete. Group II: A group of twenty-three ovariectomized females was injected daily with $5 \mathrm{mg}$ progesterone (Primolut, Berlimed Labs.) and was bled $24 \mathrm{hr}$ after the last injection. Four females received one injection, four females received two injections and fifteen females received five injections of progesterone. Group III: A group of ten ovariectomized females was injected daily with $1 \mu$ g oestradiol benzoate for 9 consecutive days. They were bled $24 \mathrm{hr}$ after the last injection. Group IV: A group of twelve females was injected daily with $1 \mu \mathrm{g}$ oestradiol and $5 \mathrm{mg}$ progesterone for 5 days. They were bled $24 \mathrm{hr}$ after the last injection.

An additional ten females were primed with a daily injection of $1 \mu \mathrm{g}$ oestradiol benzoate for 9 days. During an additional period of 5 days, they received oestrogen and progesterone.

\section{RESULTS}

Effect of the reproductive phase on the ability of blood serum to induce the acrosome reaction

Normal cycling females. Blood serum from sixty-one females was used in this series of experiments. The results (Text-fig. 1 and Table 2) show a variation in

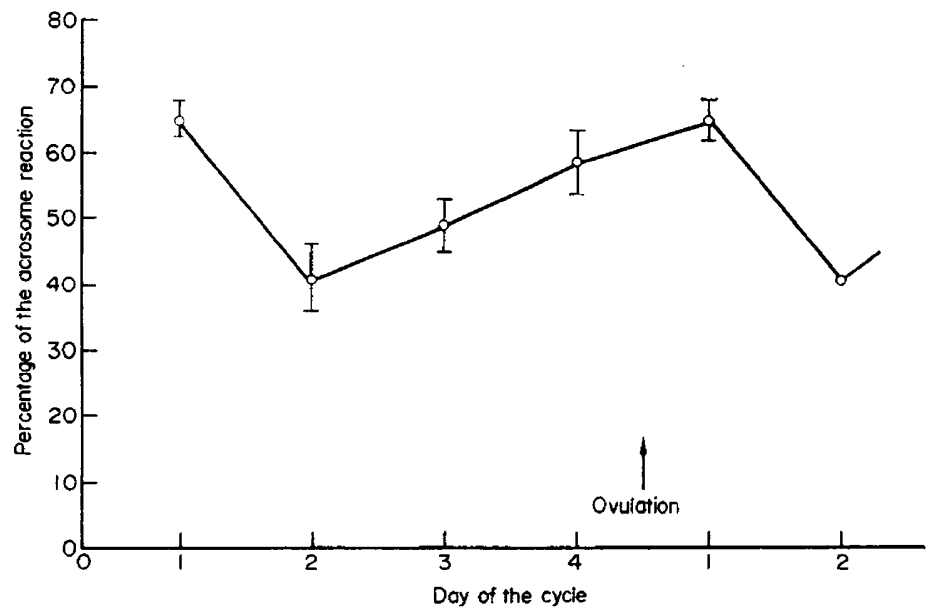

TExT-Fio. 1. Mean percentage acrosome reactions with female hamster blood serum on the 4 days of the oestrous cycle. The vertical bars represent \pm S.E.

the mean percentage of acrosome reactions through the oestrous cycle. The mean percentage of acrosome reactions obtained with blood serum of females 
on Day 1 was $65 \cdot 0 \pm$ S.E. $3 \cdot 1$; with blood serum from females on Day 2 it was $41 \cdot 0 \pm 5 \cdot 1$; with blood serum from females on Day 3 it was $49 \cdot 0 \pm 3 \cdot 6$; and with blood serum from females on Day 4 it was $57 \cdot 0 \pm 4 \cdot 9$. The results also show (Table 3) significant differences between Day 1 and Day $2(P<0.001)$; between Day 1 and Day $3(P<0.01)$; and between Day 2 and Day $4(P<0.02)$.

TABLE 2

MEAN PERGENTAGE ACROSOME REAGTIONS OF HAMSTER SPERMATOZOA INGUBATED IN FEMALE BLOOD SERUM FOR THE 4 DAYS OF THE OESTROUS GYGLE

\begin{tabular}{c|c|c|c|c}
\hline $\begin{array}{c}\text { Day of } \\
\text { cycle }\end{array}$ & $\begin{array}{c}\text { No. of } \\
\text { animals used }\end{array}$ & $\begin{array}{c}\text { No. of } \\
\text { experiments }\end{array}$ & $\begin{array}{c}\text { Mean } \\
\%\end{array}$ & S.E. \\
\hline Day 1 & 16 & 16 & $65 \cdot 0$ & $3 \cdot 1$ \\
Day 2 & 13 & 13 & $41 \cdot 0$ & $5 \cdot 1$ \\
Day 3 & 16 & 16 & $49 \cdot 0$ & $3 \cdot 6$ \\
Day 4 & 16 & 16 & $57 \cdot 0$ & 4.9 \\
\hline
\end{tabular}

TABLE 3

SIGNIFICANCE AND PROBABILITY OBTAINED BY STUDENT'S TEST WITH REGARD TO THE ACTIVITY OF SERA OBTAINED ON EAGK OF THE 4 DAYS OF THE OESTROUS GYGLE IN THE INDUCTION OF THE ACROSOME REACTION (SEE TABLE 2)

\begin{tabular}{c|c|c}
\hline Days of cycle & $\mathrm{t}$ & $\mathrm{P}$ \\
\hline 1 to 2 & 4.13 & 0.001 \\
1 to 3 & $3 \cdot 33$ & 0.01 \\
1 to 4 & $1 \cdot 60$ & 0.2 \\
2 to 3 & $1 \cdot 36$ & 0.2 \\
2 to 4 & $2 \cdot 30$ & 0.02 \\
3 to 4 & 1.30 & 0.2 \\
\hline
\end{tabular}

$t$, Significance; $P$, probability.

Pregnant females. The results show (Text-fig. 2, Table 4) that during pregnancy the ability of blood serum to induce the acrosome reaction is considerably depressed as compared with the serum of non-pregnant adult females. The mean percentage of the acrosome reactions in twenty-two experiments was $25 \cdot 0 \pm 3.2$.

Ovariectomized females. Blood sera from ovariectomized females kept under different experimental conditions were assayed for the incidence of the acrosome reaction.

In the series of experiments involving Group I, the uterine horns were completely atrophic, showing that ovariectomy was successful. The incidence of acrosome reactions was not affected when blood serum from ovariectomized females was used since the mean percentage of reactions was $64 \cdot 5 \pm 4 \cdot 8$, which is not significantly different from 65.0 obtained with normal females on Day 1 (see Table 5). 
In the series of experiments involving Group II, the uterine horns of females receiving one or two injections of progesterone were still as atrophic, as those of ovariectomized females receiving no progesterone treatment. However, after 5 days of treatment, the uterine horns showed a considerable weight increase characteristic of progesterone treatment.

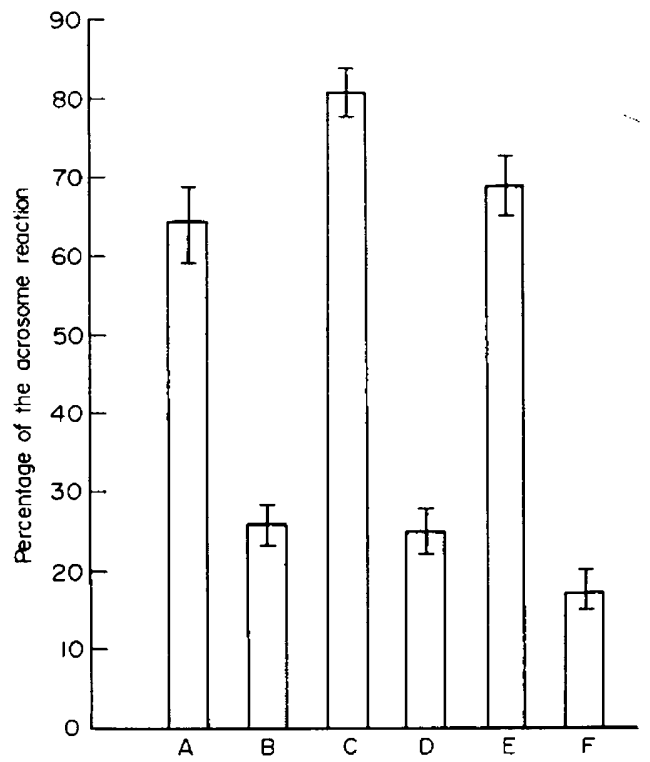

Text-Fig. 2. Mean percentage acrosome reactions of hamster spermatozoa with female blood serum under different conditions. (A) Ovariectomized females; (B) ovariectomized and progesterone-treated (5 mg for 5 days); (C) ovariectomized and oestrogentreated (1 $\mu \mathrm{g}$ for 9 days); (D) pregnant females; (E) ovariectomized and primed with oestrogen for 9 days, and then treated with both oestrogen and progesterone; $(F)$ ovariectomized and treated with oestrogen and progesterone for 5 days. The vertical bars represent \pm S.E.

TABLE 4

MEAN PERGENTAGE AGROSOME REAGTIONS OF SPERMATOZOA INGUBATED WITH BLOOD SERA FROM FEMALES UNDER DIFFERENT GONDITIONS

\begin{tabular}{|c|c|c|c|c|c|c|}
\hline $\begin{array}{c}\text { Type of } \\
\text { animals used }\end{array}$ & $\begin{array}{c}\text { Days o } \\
\text { Oestradiol } \\
(1 \mu g \text { daily })\end{array}$ & $\begin{array}{l}\text { treatment } \\
\text { Progesterone } \\
\text { (5 mg daily) }\end{array}$ & $\begin{array}{c}\text { No. of } \\
\text { animals } \\
\text { used }\end{array}$ & $\begin{array}{l}\text { No. of } \\
\text { experi- } \\
\text { ments }\end{array}$ & $\begin{array}{c}\text { Mean } \\
\%\end{array}$ & S.E. \\
\hline $\begin{array}{l}\text { (a) Ovariectomized* } \\
\text { (b) Ovariectomized } \\
\text { (c) Ovariectomized } \\
\text { (d) Ovariectomized } \\
\text { (e) Ovariectomized } \\
\text { (f) Ovariectomized } \\
\text { (g) Ovariectomized } \dagger \\
\text { (h) Pregnant (11 days) }\end{array}$ & $\begin{array}{l}- \\
\overline{-} \\
\overline{9} \\
5 \\
5 \\
-\end{array}$ & $\begin{array}{l}-1 \\
2 \\
5 \\
5 \\
5 \\
-\end{array}$ & $\begin{array}{r}41 \\
4 \\
4 \\
15 \\
10 \\
12 \\
10 \\
15\end{array}$ & $\begin{array}{r}41 \\
4 \\
4 \\
18 \\
12 \\
26 \\
24 \\
22\end{array}$ & $\begin{array}{l}64 \cdot 5 \\
63 \cdot 0 \\
60 \cdot 0 \\
26 \cdot 5 \\
81 \cdot 5 \\
17 \cdot 9 \\
69 \cdot 0 \\
25 \cdot 0\end{array}$ & $\begin{array}{l}4 \cdot 8 \\
5 \cdot 2 \\
3 \cdot 0 \\
2 \cdot 5 \\
3 \cdot 1 \\
2 \cdot 2 \\
4 \cdot 0 \\
3 \cdot 2\end{array}$ \\
\hline
\end{tabular}

* This group of females were injected with $0.2 \mathrm{ml}$ of the hormone vehicle. The results obtained with the serum of ovariectomized females injected with oil and those receiving no oil injections were not significantly different so that they have been combined in this table.

$\dagger$ Females were primed with oestrogen for 9 days. 
The ability of blood serum to induce the acrosome reaction was not significantly modified after one or two injections, but the incidence of reactions was considerably depressed after 5 days' treatment (see Table 4 ). The mean percentage of acrosome reactions obtained with this group of females was $26.5 \pm 2.5$ which is significantly different $(P<0.001)$ from the percentage obtained with blood serum of ovariectomized females receiving no treatment.

TABLE 5

SIGNIFICANCE AND PROBABILITY OBTAINED BY STUDENT'S TEST WITH REGARD TO THE ACTIVITY OF SERA OBTAINED FROM FEMALES UNDER DIFFERENT CONDITIONS

\begin{tabular}{c|c|c}
\hline $\begin{array}{c}\text { Animals compared } \\
\text { (see Table 4) }\end{array}$ & $\mathbf{t}$ & $\mathbf{P}$ \\
\hline a-d & $7 \cdot 10$ & 0.001 \\
a-c & $3 \cdot 20$ & 0.001 \\
a-g & 0.72 & 0.4 \\
a-f & 8.90 & 0.001 \\
$\mathrm{f}-\mathrm{g}$ & 11.30 & 0.001 \\
$\mathrm{~d}-\mathrm{f}$ & 2.66 & 0.01 \\
\hline
\end{tabular}

$t$, Significance; $P$, probability.

The uterine horns of the females in Group III showed an increase in weight characteristic of oestrogen treatment. Consistently, their blood serum elicited the acrosome reaction at a higher incidence than that of untreated females (see Tables 4 and 5, Text-fig. 2). The mean percentage of $81.5 \pm 3 \cdot 1$ found in this group of females was significantly different from that for untreated ovariectomized females $(P<0.001)$.

In the series of experiments involving Group IV, we studied the combined effect of progesterone and oestradiol benzoate. In the first series, ten females were primed with $1 \mu \mathrm{g}$ oestradiol benzoate for 9 consecutive days and on the 10 th to the 14th day, in addition to $1 \mu \mathrm{g}$ oestradiol benzoate, they were injected with $5 \mathrm{mg}$ progesterone. The results (see Tables 4 and 5) show that the mean percentage of acrosome reactions was $69 \cdot 0 \pm 4 \cdot 0$. This percentage was not found to be significantly different from that observed with ovariectomized females receiving no treatment $(P<0.4)$. Different results were obtained in a second series of experiments when progesterone and oestradiol benzoate treatment was begun without pretreatment with oestradiol benzoate. Blood serum from twelve females treated for 5 days with $5 \mathrm{mg}$ of progesterone and $1 \mu \mathrm{g}$ oestradiol benzoate gave a mean percentage of acrosome reactions of $17 \cdot 9 \pm 2 \cdot 2$. This percentage is significantly different from the previous one $(P<0.001)$.

\section{DISGUSSION}

We have confirmed the results of Barros \& Garavagno (1970) and of Yanagimachi (1970) with regard to the ability of blood serum to induce the acrosome reaction of hamster spermatozoa. 
The new findings in the present work are related to the dependence of this activity on the reproductive phase of the female hamster. The cyclic changes observed in the ability of blood serum to induce the acrosome reaction through the oestrous cycle would indicate a close correlation between the female sex hormones and the action of the active agent(s) present in the serum. This cyclic activity might be in agreement with the changes in the levels of progesterone and oestrogens during the cycle.

The lowest incidence of the acrosome reaction appeared on Day 2 of the cycle, which correlates with the finding of Lukaszewska \& Greenwald (1970) of a maximum blood progesterone level on Day 2. On the other hand, the highest percentage of the acrosome reaction was found to correspond with the day of ovulation. This latter fact would be expected since it would be necessary to have the highest activity at the time when fertilization normally occurs.

It was interesting to find that after ovariectomy, the activity of blood serum was similar to that found in normal females on Day 1. We are aware of the fact that the hamster and the rabbit might be different biological models with regard to sperm capacitation but a few comparisons seem appropriate. Chang (1958) found that rabbit spermatozoa, incubated in the uterus of an oestrous doe, could fertilize $63 \%$ of the eggs, while those incubated in the uterus of an ovariectomized female could fertilize $37 \%$ of the eggs. Chang's results would agree with our's in the sense that ovariectomy does not inhibit capacitation. However, Soupart (1967) found that rabbit spermatozoa, incubated in the uterus of an ovariectomized doe, yielded only $4.2 \%$ of fertilized eggs. Moreover, he found a dose-response relationship of capacitation with increasing doses of oestradiol benzoate injected into ovariectomized females. The maximum activity corresponded to a dose of $1 \mu \mathrm{g} / \mathrm{kg}$ of body weight. At higher doses, the capacitation process was slowly depressed. In spite of the fact that we did not find a depression in the ability of blood serum to induce the acrosome reaction after ovariectomy, we did find that the acrosome reaction was enhanced after oestrogen treatment. The mean percentage of $81.5 \%$ of acrosome reactions in ovariectomized females treated with oestradiol benzoate was significantly different from the percentage with ovariectomized females receiving no oestrogen treatment $(P<0 \cdot 001)$.

The present work has also shown that progesterone has a powerful inhibitory effect on the ability of blood serum to induce the acrosome reaction. The percentage of acrosome reactions with ovariectomized females treated with progesterone was not significantly different from that obtained with blood serum from pregnant females. These results would agree with those of Chang (1958) and Hamner et al. (1968), who reported that rabbit spermatozoa do not gain the capacity to fertilize eggs when they are incubated in the uterus of a pseudopregnant female.

This suggestion is perhaps further supported by the fact that many oral contraceptives containing progestational compounds exert an inhibitory effect on fertilization by inhibition of sperm capacitation (Chang, 1967, 1969).

Our results also show that there is an interaction between the effects of oestrogen and progesterone which affects the ability of blood serum to induce the acrosome reaction. Thus, serum obtained from oestrogen-treated females 
which are later treated with progesterone can induce the acrosome reaction to a degree which is similar to that of blood serum obtained from ovariectomized females with no oestrogen treatment, and also similar to that found in normal cycling females on Day 1. The effect of blood serum from oestrogen-primed females is counteracted by progesterone. The counteracting effect of progesterone was more pronounced when both hormones were administered to ovariectomized females which had not been primed with oestrogen. In these circumstances, the mean percentage was 17.9 which is significantly different from $26.5 \%$ found for ovariectomized females treated with progesterone $(P<0.01)$. A similar inhibitory effect on capacitation was found by Soupart (1970) in oestrogen-primed rabbit females treated with high doses of $20 \alpha-$ hydroxypregn-4-en-3-one. It would seem that oestrogen treatment augments the effect of progesterone (Martin, Finn \& Carter, 1970).

The question of what rôle the hormones play in controlling the ability of blood serum to induce the acrosome reaction is one that cannot be answered at the present time, since we do not yet know the nature of the active agent involved in this process. Yanagimachi (1969b) showed that the active agent(s) of bovine follicular fluid is (are) present in the macromolecular fraction. The active agent of blood serum also appears to be present in the macromolecular fraction (Yanagimachi, 1970; Barros \& Garavagno, unpublished observation). This fact does not rule out the possibility that the active agent(s) might be molecules of low molecular weight and bound to the proteins of blood serum. Both oestrogen and progesterone are bound to serum proteins (Williams, 1964). On the other hand, Gwatkin \& Williams (1970) studied the effect in vitro of several steroids on hamster sperm capacitation. They found that the progestagen, chlormadinone acetate, was the most effective agent to inhibit capacitation as judged by fertilization in vitro, but sperm motility was greatly reduced. Capacitation was also inhibited with $17 \beta$-oestradiol but at a dose of $50 \mu \mathrm{g} / \mathrm{ml}$, which is much higher than the physiological one. At lower doses $(2 \mu \mathrm{g} / \mathrm{ml})$, they found an incidence of capacitation similar to that of the control group $(28 \%)$.

Our results would not lend support to the idea of a direct effect of oestrogen and progesterone on the acrosome reaction, because of the high incidence of acrosome reactions found with the blood serum of ovariectomized females and with the blood serum of males (see Table 1), unless we accept that the amounts of oestrogen secreted by the testis (Williams, 1964) and adrenal glands (Zarrow, Jochim \& McCarthy, 1964) would be enough for the induction of the acrosome reaction.

The same argument could be advanced for the possible controlling action of oestrogen and progesterone on the synthesis of the active agent(s).

A more likely possibility is that both hormones could control the action of the active agents. It is known that the incidence of the acrosome reaction could be modified not only with regard to the hormone administered, but also with regard to the interrelationship between the hormones. This interrelationship makes it conceivable that the active agents may be present in the female tract at all times, but may become active only at the time of fertilization. 


\section{ACKNOWLEDGMENTS}

We are indebted to Professor C. R. Austin for reading this manuscript. Grateful acknowledgments are due to $\mathrm{Mr}$ Ronald Michels for suggestions which improved the English presentation for this manuscript.

This work was supported by Grants: 6856 from The Rockefeller Foundation; 190/68 from the Comision Nacional de Investigacion Cientifica y Tecnologica and 9/69 from the Catholic University of Chile.

\section{REFERENCES}

Barros, C. \& Austin, C. R. (1967) In vitro fertilization and the sperm acrosome reaction of hamster spermatozoa. F. exp. Zool. 166, 317.

Barros, C. \& Garavagno, A. (1970) Capacitation of hamster spermatozoa with blood sera. J. Reprod. Fert. 22, 381 .

Chang, M. C. (1958) Capacitation of rabbit spermatozoa in the uterus with special reference to the reproductive phases of the female. Endocrinology, 63, 619.

Chang, M. C. (1967) Physiological mechanisms responsible for the effectiveness of oral contraceptives. Proc. of the 8th International Conference of the IPPF, Santiago, Chile, p. 386.

Chang, M. C. (1969) Fertilization, transportation and degeneration of eggs in pseudopregnant or progesterone-treated rabbits. Endocrinology, 84, 356.

Gwatkin, R. B. L. \& Andersen, O. F. (1969) Capacitation of hamster spermatozoa by bovine follicular fluid. Nature, Lond. 224, 1111.

Gwatkin, R. B. L. \& Wrlliams, D. T. (1970) Inhibition of sperm capacitation in vitro by contraceptive steroids. Nature, Lond. 227, 182.

Hamner, C. E., Jones, J. P. \& Sojka, N. J. (1968) Influence of the hormonal state of the female on the fertilizing capacity of rabbit spermatozoa. Fert. Steril. 19, 137.

Lukaszewska, J. H. \& Greenwald, G. S. (1970) Progesterone levels in the cyclic and pregnant hamster. Endocrinology, 86, 1.

Martin, C., Finn, C. A. \& Carter, J. (1970) Effects of progesterone and oestradiol-17 $\beta$ on the luminal epithelium of the mouse uterus. F. Reprod. Fert. $21,461$.

Orsini, M. W. (1961) The external vaginal phenomena characterizing the stages of the estrous cycle, pregnancy, pseudopregnancy, lactation and the anestrous hamster Mesocricetus auratus Waterhouse. Proc. Anim. Care Panel, 11, 193.

Soupart, P. (1967) Studies on the hormonal control of rabbit sperm capacitation. F. Reprod. Fert., Suppl. 2, 49.

Soupart, P. (1970) Inhibitory effect of 20 $\alpha$-hydroxypregn-4-en-3-one on sperm capacitation in the rabbit uterus: in vivo and in vitro fertilization assays. Biol. Reprod. 3, 1 .

Wettemann, R. P. \& Hafs, H. D. (1970) Sperm capacitation after injection of LH or Hgg in rabbits. Proc. Soc. exp. Biol. Med. 133, 1002.

Williams, R. H. (1964) Textbook of endocrinology. W. B. Saunders, Philadelphia.

YANAGIMAGH, R. (1969a) In vitro capacitation of hamster spermatozoa by follicular fluid. $\mathcal{F}$. Reprod. Fert. 18, 275.

YANAGIMACHI, R. (1969b) In vitro acrosome reaction and capacitation of golden hamster spermatozoa by bovine follicular fluid and its fractions. 7. exp. Zool. 170, 269.

YANAGIMAGHI, R. (1970) In vitro capacitation of golden hamster spermatozoa by homologous and heterologous blood sera. Biol. Reprod. 3, 147.

Zarrow, M. X., Jochim, J. M. \& McСаrthy, J. L. (1964) Experimental endocrinology. Academic Press, New York. 